\title{
Social and Environmental Conflicts in the Peruvian Amazon ${ }^{1}$
}

\author{
Katalin Jancsó ${ }^{2}$
}

\begin{abstract}
The Peruvian Amazon remained relatively undisturbed until the 1860s, with higher immigration and the extraction of raw materials only beginning in the second half of the century. As a result of the rubber boom (1880-1910), many ethnic groups became extinct. During the $20^{\text {th }}$ century, the exploitation of mahogany, cedar, and other useful trees, the cultivation of various plants and also, in some regions, gold mining began. In the last decades of the $20^{\text {th }}$ century, the extraction of oil and other raw materials as well as the construction of roads and infrastructure led to a significant reduction in forest areas. Further developments are planned for the upcoming years. Illegal gold mining, oil extraction and deforestation are expected to intensify, with increasing local social resistance, one of the most prominent examples being the bloody conflict between the Peruvian army and local ethnic groups in 2009 in the city of Bagua. A growing number of non-governmental organizations are protesting against the processes taking place in the region. The purpose of this study is to provide a background for the understanding of these processes and present the current situation.
\end{abstract}

Keywords: Peruvian Amazon, deforestation, social conflicts

\section{The Peruvian Amazon}

The world's most biodiverse region, the Amazon Basin comprises nine countries, covering 7.8 million $\mathrm{km}^{2}$. After Brazil, Peru is the second largest country in the Amazon, with an estimated 40,000 species of animals and plants living there (BIODAMAZ, 2004:

\footnotetext{
1 This research was supported by the project no. EFOP-3.6.2-16-2017-00007, titled "Aspects on the development of intelligent, sustainable and inclusive society: social, technological, innovation networks in employment and digital economy". The project has been supported by the European Union, co-financed by the European Social Fund and the budget of Hungary.

${ }^{2} \mathrm{PhD}$ in Modern History, Associate Professor at the Department of Hispanic Studies, University of Szeged. The focus of her research is the history and the social and economic situation of minorities (native people, women) and immigrants (Asians, Hungarians) in Latin America.
} 
30). With its area of nearly $780,000 \mathrm{~km}^{2}$, the Peruvian Amazon, which covers about $60 \%$ of the country, is home to more than 330,000 indigenous people (INEI, 2016, IIAP, 1998). They belong to 13 language families, nearly 60 ethnicities, and live in 1,786 communities, of which about eight-hundred have reported conflicts with the outside world in recent years (Sánchez Aguilar, 2011: 17-43). The number of these conflicts has multiplied between 2006 and 2011, leading to the death of almost two hundred people (civilians and police officers) (Ardito 2012: 11). Survival International estimates that about fifteen ethnic groups in the most remote areas of the rainforest are still completely isolated, but their habitat is increasingly shrinking due to civilized human activities (Survival, d.n.i.). This article presents the environmental and social processes and conflicts that have occurred in this area in recent years.

\section{Changes in the $20^{\text {th }}$ Century}

Extractive activities began in the area in the $19^{\text {th }}$ century; consequently, due to the rubber boom and the demand for caucho and cinchona, extractive companies appeared forcing aboriginal people to work as slaves (Jancsó, 2011: 4-10).

By the beginning of the $20^{\text {th }}$ century, as a result of falling international market prices, the civilized world's presence in the region declined and the territory remained relatively undisturbed until the Second World War. From 1941, the Japanese occupation of Southeast Asian regions (from where 98\% of the world's rubber demand was sourced) once again drew international markets' attention to the Amazon rubber deposits. Extraction thus intensified again, all the way up to the 1950s. From the 1920s, mahogany and cedar became the two most important valuable trees in Loreto, and by that time agricultural production also had begun (Meza - Sabogal - de Jong, 2006: 36).

From the 1950s to the 1960s, the Peruvian Amazon underwent major economic and social changes. The measures introduced by Juan Velasco Alvarado's military government (1968-1975) proved to be important factors in this process. The radical agricultural reform (1969) mainly affected the coast and the Andes, but it also had an effect on the Amazon region. As an element of the agricultural reform, the Forest Agrarian Promotion and Native Communities Law was adopted in 1974 to regulate access to land. The law recognized the property rights of native communities living in the region (Eguren López, 2006: 13). However, this also meant that the government expected traditionally nomadic communities to have a permanent habitat. The autonomy 
aspirations and the rise of political organizations of the Amazonian communities began at that time (Villalobos Ruiz, 2016).

Also, in the 1960s, the previously bidirectional processes of migration between the Andes and the Amazon region intensified. Andean people came to settle in the hope of employment and land acquisition (Aramburu, 1979: 85-90). State-supported settlements played a major role in reducing land hunger among the Andean ethnic groups (Meza - Sabogal - de Jong, 2006: 21). The process gained new momentum from the 1990s. The settlement projects and the integration of Amazonian territories led to social conflicts and had negative environmental effects.

In the 1980s, the Amazon region was under additional pressure. The Maoist terrorist organization, the Shining Path, was first active in the Southern Andean Highlands, but soon wanted to influence the Amazon region as well. Military violence began in 1980-82. Clashes with state armed forces resulted in tens of thousands of victims between 1980 and 2000, peaking between 1989 and 1994. In the 2000s, the strength of the organization weakened, its leaders were imprisoned, and from that time on, they became more active in cocaine trafficking (Villasante Cervello, 2014: 12-13). Senderists, in the hope of establishing social equality, won many native leaders for their cause. At the same time, communities feared retaliation: if anyone wanted to co-operate with the authorities, the terrorists responded violently. In the areas controlled by the Senderists, the most affected ethnic group was the Asháninka, living near the Peruvian-Brazilian border (Ardito, 2012: 24). Native people were kidnapped, were held captives in their camps and were forced to work in the fields. Their women were used to raise child soldiers for the movement (Villasante Cervello, 2014: 13-14).

\section{Contemporary Challenges and Crises}

The most serious problems in recent decades in the Amazonian region are the results of five activities: settling and the consequent expansion of agricultural land, extracting hydrocarbons, small-scale gold mining, and infrastructure development.

Mining accounts for 17\% of Peru's GDP and half of its exports. The country has become one of the largest producers of copper, silver, zinc, and gold worldwide over the past two decades, and there is strong government support for stimulating private investment. In 2014, more than 50,000 mining concessions were in force, affecting $18 \%$ of the territory of the country. These figures do not reflect illegal extraction activities, which are typical of rainforest areas (Bebbington, 2018: 19). According to Peruvian law, 
extraction projects are also permitted in areas inhabited by native communities living in voluntary isolation (except in the lower section of the Urubamba Valley) (Bebbington, 2018: 23). Oil production is the most important activity in the Amazon, and it has been the main source of conflicts in recent years. The oil industry increased and revitalized in the 1970s, which was subsequently influenced by the economic crisis of the 1980s. Due to a lack of investors, the poor management of Petroperú, a state-owned company established under the government of Velasco Alvarado and a shortage in oil production, the Peruvian government offered foreign companies investment opportunities. From this time on, intensive extraction began in the Peruvian oil fields, about $70 \%$ of which are located in the Amazon (OSINERGMIN, 2017: 72).

New laws introduced during the 1990s under Alberto Fujimori's presidency supported the presence of private capital and extractive activities. The post-Fujimori presidents pursued similar policies, increasing social tensions. Bills and regulations related to the Free Trade Agreement between Peru and the United States, ratified in 2006, and entered into force from 2009 during Alan García's presidency, favoured private investment in the areas of indigenous and agricultural communities, and facilitated the sale and subdivision of land (Durand, 2011: 1). Decree 1064 made it possible to reclassify state forest lands as agricultural lands for private investments, while Decrees 1081 and 1083 created the conditions to open up freshwater and forest lands in the territories of native communities to the market. In line with domestic policy processes, foreign capital investment showed strong growth, with investments in mining multiplying between 2007 and 2012, as visible in Table 1.

\begin{tabular}{|l|l|}
\hline Year & Amount of investments, USD \\
\hline 2007 & $1,248,815,722$ \\
\hline 2008 & $1,708,059,306$ \\
\hline 2009 & $2,821,596,371$ \\
\hline 2010 & $4,069,194,284$ \\
\hline 2011 & $7,242,590,929$ \\
\hline 2012 & $8,568,256,259$ \\
\hline
\end{tabular}

Table 1. Mining investments, 2007-2012 (BEM 2013: 16)

Between 2007 and 2010, as investments increased, the number of oil concessions also multiplied, and new explorations began. Most of the sites are in the territory of indigenous 
communities. In 2005, there were 28 existing contracts for oil extraction in the country, while in 2009, there were already 68 existing contracts (Soplin Rios, 2011: 28).

Independent observers expressed serious doubts about the changes and regulations introduced by the government. They indicated a lack of prior consultation with indigenous communities, violations of many aspects of the Peruvian Constitution, and they also pointed out that laws and decrees contradicted the Indigenous and Tribal Peoples Convention (the ILO Convention 169) and the United Nations Declaration on the Rights of Indigenous Peoples (FIDH 2009: 15-16). Protests from indigenous communities and the actions of law enforcement organizations increased, which were not alleviated by the 2008 establishment of the Ministry of Environment. As a result of oil and gold mining, large watersheds became polluted (by oil and mercury), the main problem being the use of corroded oil pipelines for decades. According to the Supervisory Agency for Investment in Energy and Mining (OSINERGMIN), there were about 190 oil spill accidents between 1997 and 2016. A glaring example is the 854-kilometer oil pipeline operated by Petroperú, that transports oil from the Amazon, across the Andes, to the Pacific coast (Fraser, 2016, 24-09-2019).

Social conflict peaked in 2008-2009. In March 2008, Achuar people occupied an airport of the PlusPetrol oil company as a sign of their protest. In July of the same year, the Interethnic Association for the Development of the Peruvian Rainforest (AIDESEP) called indigenous communities of the rainforest region for a general strike in the Amazonia. As a result of the strikes, which lasted for almost three months, some of the aforementioned regulations were withdrawn by Alan Garcia's government. Strikes in the province of Bagua resumed in March 2009 in protest against further regulations (Durand, 2011: 2). In June, the members of indigenous organizations shut down a roadway on the Fernando Belaúnde Terry motorway. The government launched a police action to solve the problem, which led to bloody clashes, killing 33 people. Following the events, fifty Awajun and Wampi Indians were arrested. Several human rights organizations protested against the circumstances of the official actions and proceedings (Cerqueira - Salazar, 2016: 3-4). Most reports in recent years come from Peru's largest oil field, the oil lot 192 near the Peru-Ecuador border, currently under the control of Perupetro. Due to the environmental and social impact of oil spills, a 100-day strike was held in Loreto in 2016; then, in December 2016, the Peruvian government and indigenous organizations signed an agreement in Saramurillo to establish a committee to investigate what had happened in the last four decades of oil extraction (Sierra Praeli, 2017). 
Gold mining in the Amazon is also a source of ongoing conflicts in Peru. The country is Latin America's leading gold exporter, ranked sixth by the World Gold Council in 2018 (World Gold Council, 2019). In rainforest areas, the main activities are illegal manual and small-scale gold mining. Compared to other gold-mining areas, the amount of gold mined is not high, therefore extraction requires mercury. Various studies report serious problems in the region of Madre de Dios, as extraction activities threaten the biodiversity and living conditions in the area. In addition to deforestation, researchers are constantly measuring elevated mercury levels in both soil and river waters in gold mining areas (Markham - Sangemano, 2018). The gold price boom dates back to the early 2000s. The peak came after the 2008 global crisis. Another impetus was the construction of the Interoceanic Highway between 2006 and 2011 and its last step, the completion of the bridge over the Madre de Dios River in 2012. As a result of gold mining activities, approximately 95,750 hectares of forest were cut down between 1985 and 2017, and tree felling increased by $425 \%$ during the years the highway was being built. Between 2009 and 2018, deforestation increased by an additional $240 \%$ due to mining activities in the area (Three decades, 2018: 2). Between 2010 and 2015, the main cause of deforestation in the area was mining (Caballero et al., 2018: 7).

However, there are other causes of deforestation besides mining. Deforestation and land degradation have intensified as a result of processes of immigration and the clearing of new land for cultivation and cattle-ranching. Founded in 1973, ENDEPALMA aimed to develop African palm tree plantations in response to growing international palm oil needs. Whereas up to 1973 only half a million, by 1990 more than 1 million hectares of land were cultivated (Meza - Sabogal - de Jong, 2006: 38).

The harvest of valuable trees is another cause of deforestation. It has gained new impetus since the early 2000s. In 2001, Brazil suspended its commercial mahogany trade, making Peru one of the world's largest suppliers of this timber. The last production areas of native cedar and mahogany trees are located in remote territories of the Peruvian Amazon, usually in areas far from the civilized world, inhabited by Indians, in national parks and indigenous reserves. It is estimated that about $75-80 \%$ of the Peruvian timber production and exports is derived from illegal activities annually. Tree felling has a negative impact on wildlife and on the indigenous communities of the region. Members of these ethnic groups migrate to other areas as well as try to protest against the process, while others become illegal loggers in the hope of thus making a living (Lorente Laforest, 2013). The deforestation process in Peru has been accelerating over the last two decades: 
while it affected $830 \mathrm{~km}^{2}$ per year in 2001 and $1770 \mathrm{~km}^{2}$ in 2014, the Peruvian Ministry of Environment predicts an annual forest loss of $3500 \mathrm{~km}^{2}$ by 2030 (Rojas Briceño, 2019: 3). Looking at percentages and starting with the year of 2000, Peru lost $3.7 \%$ of its forested areas by 2018. This figure was $10 \%$ in Brazil, $7.5 \%$ in Bolivia, 5\% in Colombia and $4.1 \%$ in Ecuador, respectively (Global Forest Watch, 2018). In many cases, labour demand is met by forced labour; young native men are forced to work with mestizo people and Andean indigenous immigrants under circumstances violating occupational health and safety regulations. Workers are served by indigenous women, who are often victims of sexual violence (Mujica, 2015: 22).

The already mentioned infrastructural developments in recent decades are also among the leading causes of deforestation: roads in rainforest areas act as catalysts, facilitating access to isolated areas and accelerating tree felling (the construction of river and land roads is responsible for $62 \%$ of total forest loss) (Servicio, 2015). The construction of the Interoceanic Highway has been a major factor in the deforestation process of recent years. In parallel with the construction, a large number of settlers created private plantations in the area around the road, which generated further difficulties. In addition, many planned investments and infrastructure projects pose a threat to environmentally valuable or untouched areas and the habitats of isolated communities. One of Peru's most significant Shell-related energy projects is the pipeline between the Camisea Gas Fields and South Peru, in a highly biodiverse Indian-populated rainforest region (Hydrocarbons Technology, 2019). Extraction began in 2004, with harmful consequences such as deforestation, the pollution of one of the world's largest biodiversity areas, the loss of fish stocks in the waters of the region, initial contacts with isolated communities, the introduction of various diseases, higher mortality rates, the construction of new roads and the intensification of migration processes (Parks Watch, 2019). Another project with many risks is the Iquitos-Moyobamba Transmission Line, which will carry electricity to the rainforest area with an estimated length of $600 \mathrm{~km}$. The implementation of the Amazon Waterway Project linking the Amazon, Marañón, Huallaga and Ucayali rivers, led by a Chinese company, is also in progress with the main goal of ensuring the continuous navigability of these rivers (Bebbington, 2018: 34). Controversial projects in recent years include the 273-km-long Puerto Esperanza - Iñapari highway plan, submitted in 2016. The highway would lead through the Alto Purus National Park, the Purús Communal Reserve and the Madre de Dios Territorial Reserve created for indigenous people in isolation (Upper Amazon Conservancy, 2019). The last, still unconstructed 
section of the Interoceanic Highway would lead from Cruzeiro do Sul, Brazil to Pucallpa in Ucayali, Peru. Due to negotiations in recent years, the construction of a more environmentally friendly railway line is now being negotiated instead of the previously planned highway (Hopkins et al., 2014: 2-4).

\section{The Future of the Peruvian Amazon}

Some international, governmental and non-governmental initiatives have appeared in recent years focusing on the sustainability of the Amazon region. The issue is very complex, with countless interests at stake, and often there is no consensus even within indigenous communities on what projects to support. The improvements can mean closer links with major cities, job opportunities and incomes; there are some communities whose members are unaware of the negative environmental impacts of such developments. AIDESEP brings together many regional organizations in the area and represents the rights of more than 1,800 communities at the national level. Various international organizations (UN, Greenpeace, World Wildlife Fund) are also active in the region through different programs. In addition, there are transnational co-operation projects, the co-ordination of which takes place at the summits organized by the Amazonian countries. The last summit was held in September 2019 in Leticia, Colombia, where seven countries (Bolivia, Brazil, Colombia, Ecuador, Guyana, Peru and Suriname) signed the Leticia Pact for the Amazon (Siete países, 2019).

Serious efforts have been made in recent years to repopulate the deforested areas of rainforest. In cooperation with USAID, WWF and other organizations, a reforestation program was launched in 2015; in the region of Madre de Dios to begin with. The Ministry of the Environment also launched a similar project, first in the Manu Reserve, with the participation of indigenous communities. The projects established the first seedling plantation in the region of Madre de Dios, which will provide sapling trees for further planting (WWF, 2017). Peru also joined the sub-continent's tree-planting initiative, known as the 20x20, launched in 2014. The Initiative 20x20 is seeking to have 20 million hectares of land reforested by 17 Latin American states by 2020. The commitment of Peru is the reforestation of 3.2 million hectares (Perú busca 2018). Examples of local initiatives include the Alto Purús National Park and the Purús Communal Reserve, created in 2004 by a joint effort of local indigenous communities and WWF Peru (WWF, 2011). 


\section{Conclusion}

The Peruvian Amazon is one of the largest biodiversity areas in the world and is home to isolated indigenous peoples as well as communities that have contacts with modern society. In recent decades, the intensity of extraction activities has increased, and some of the formerly designated national parks are now threatened by oil and mining concessions and illegal activities (logging, mining). The emergence of several companies is linked to the public policies that encourage private equity investments. As a result of the pressure on indigenous communities, social conflicts have arisen, with growing local resistance to illegal gold mining, oil extraction, infrastructure projects, and land clearing for agricultural use. Isolated groups try to migrate to remote areas of the rainforest. However, various infrastructure developments are often planned exactly in these areas. As a result of human activities and infrastructure projects, the deforestation of the rainforests is accelerating, which could not even be slowed down by the reforestation activities of regional, national and international organizations and associations.

\section{References}

Aramburú, Carlos (1979): Las migraciones a las zonas de colonización en la selva peruana: perspectivas y avances, Debates en Sociología, 4/1979, 81-94.

Ardito, Wilfredo (ed.) (2012): Conflictos en la Amazonía. Diagnóstico. Mitigación de conflictos sociales y desarrollo de la Amazonía, USAID - CAAAP - CEAS.

Bebbington, Denise Humphreys et. al. (2018): Impacts of extractive industry and infrastructure on forests, Climate and Land Use Alliance.

BIODAMAZ Peru-Finlandia (2004): Estrategia Regional de la Diversidad Biológica Amazónica, IIAP. Available at: http://minagri.gob.pe/portal/download/pdf/sectoragrario/recursos_naturales/ERD BA.pdf (accessed: 15 June 2019).

Caballero, Jorge et. al. (2018): Deforestation and Forest Degradation Due to Gold Mining in the Peruvian Amazon: A 34-Year Perspective, Remote Sensing, 10(12), Nov. doi:10.3390/rs10121903 (accessed 23 July 2019).

Cerqueira, Daniel - Salazar, Katya (2016): La sentencia sobre los hechos de violencia en la Curva del Diablo. Comentarios a la luz de estándares internacionales de derechos humanos, DPLF, Washington. Available at: http://www.dplf.org/sites/default/files/bagua_v2.pdf (accessed 12 July 2019). 
Durand, Anahí (2011): ¿Tierras de nadie? Actividad extractiva, territorio y conflicto social en la Amazonía peruana: el río Cenepa, CISEPA.

Eguren López, Fernando (ed.) (2006): Reforma agraria y desarrollo rural en el Perú, CEPES.

Federación Internacional de Derechos Humanos (FIDH) (2009): Perú - Bagua. Derramiento de sangre en el contecto del paro amazónico urge abrir diálogo de buena $\quad f e, \quad$ Octubre/09, N529e. Available at: https://www.fidh.org/IMG/pdf/amer/pe529e.pdf (accessed 15 July 2019).

Fraser, Barbara (2016): Protestas y negociaciones tras derrames de petróleo en la Amazonía peruana, Mongabay Latam. Available at: https://es.mongabay.com/2016/09/protestas-negociaciones-tras-derramespetroleo-la-amazonia-peruana/ (accessed 17 July 2019).

Global Forest Watch. Available at: https://www.globalforestwatch.org (accessed 3 August 2019).

Hopkins, Álvaro et. al. (2014): Infraestructura y conservación. El caso PucallpaCruzeiro do Sul, USAID - GRADE - The Nature Conservancy. Available at: https://www.conservation-strategy.org/sites/default/files/fieldfile/CSF_B_enero_Final_ES_web.pdf (accessed: 12 September 2019).

Hydrocarbons Technology, Camisea Gas Project and Gas Processing Plant, Peru. Available at: https://www.hydrocarbons-technology.com/projects/camisea/ (accessed 30 August 2019).

IIAP - Instituto de Investigaciones de la Amazonia Peruana (1998): Delimitación del territorio amazónico con criterio ecológico y con criterio hidrográfico. Available at: http://repositorio.iiap.org.pe/bitstream/IIAP/204/11/IIAP_DOCU_1998.pdf.pdf (accessed: 11 June 2019).

INEI - Instituto Nacional de Estadística e Informática. Available at: https://www.inei.gob.pe (accessed 23 June 2019).

Instituto Nacional de Estadística e Informática (2016): Población indígena de la Amazonía peruana supera los 330 mil habitantes. Available at: https://www.inei.gob.pe/prensa/noticias/poblacion-indigena-de-la-amazoniaperuana-supera-los-330-mil-habitantes-9232/ (accessed: 10 June 2019).

Jancsó, Katalin (2011): Kaucsukláz a perui Amazóniában, Világtörténet, 1-2/2011. 1-12. 
Lorente Reforest (2013): La caoba, el oro rojo en peligro. Available at: https://www.lorentereforest.com/la-caoba-el-oro-rojo-en-peligro/ (accessed 24 September 2019).

Markham, K.E. - Sangemano, F. (2018): Evaluating Wildlife Vulnerability to Mercury Pollution from Artisanal and Small-Scale Gold Mining in Madre de Dios, Peru, Tropical Conservation Science, Volume 11. Available at: https://journals.sagepub.com/doi/full/10.1177/1940082918794320 (accessed 27 July 2019).

Meza, Abel - Sabogal, César - de Jong, Wil (2006): Rehabilitación de áreas degradadas en la Amazonia peruana. Revisión de experiencias y lecciones aprendidas, CIFOR.

Ministerio de Energía y Minas (2013): Boletín Estadístico de Minería (BEM), № $02-$ 2013, Lima. Available at:

http://www.minem.gob.pe/minem/archivos/file/Mineria/PUBLICACIONES/VARIABL ES/2013/mayo.pdf (accessed 29 June 2019).

Mujica, Jaris (2015): Precariedad y trabajo forzoso en la extraccción de madera. Un estudio en espacios rurales de la Amazonía peruana, Organización Internacional del Trabajo, Peru.

OSINERGMIN (2017): La industria de los hidrocarburos en el Perú, Lima.

Parks Watch: Machiguenga Communal Reserve. Available at: http://www.parkswatch.org/parkprofile.php?l=eng\&country=per\&park=macr\&p age $=$ thr (accessed 30 August 2019).

Perú busca restaurar 3.2 millones de hectáreas de tierras degradadas, Andina, 26-04-2018. Available at: https://andina.pe/agencia/noticia.aspx?id=707956 (accessed 30 September 2019).

Rojas Briceño, Nilton Beltrán et. al. (2019): Deforestación en la Amazonía peruana: índices de cambios de cobertura y uso del suelo basado en SIG, Boletín de la Asociación de Geógrafos Españoles, 81/2019, 1-34. http://dx.doi.org/10.21138/bage.2538a

Sánchez Aguilar, Aníbal (ed.) (2011): Características Sociodemográficas de los Grupos Étnicos de la Amazonía Peruana y del Espacio Geográfico en el que Residen, INEI - UNFPA. Available at:

http://proyectos.inei.gob.pe/web/biblioineipub/bancopub/Est/Lib0944/index.htm (accessed 15 June 2019). 
Servicio Nacional Forestal y de Fauna Silvestre (2015): Interpretación de la dinámica de la deforestación en el Perú y lecciones aprendidas para reducirla. Available at: http://repositorio.serfor.gob.pe/handle/SERFOR/248 (accessed 12 July 2019).

Sierra Praeli, Yvette (2017): ¿Qué ha pasado en 40 años de actividad petrolera en la Amazonía peruana?, Mongabay Latam. Available at: https://es.mongabay.com/2017/06/ha-pasado-40-anos-actividad-petrolera-laamazonia-peruana/ (accessed 24 September 2019).

Siete países de la Amazonía firman el Pacto de Leticia para proteger la selva, El Confidencial, 07-09-2019. Available at: https://www.elconfidencial.com/mundo/2019-09-07/pacto-leticia-protegeramazonas-incendios-deforestacion_2214767/(accessed 30 September 2019).

Soplin Rios, José Antonio (2011): Perspectivas a futuro en la extracción petrolera y sus impactos, PeruPetro S.A. Available at: http://www.actualidadambiental.pe/wpcontent/uploads/2011/11/Pespectiva-de-Extraccion-Petrolera-y-sus-impactos.pdf (accessed 28 September 2019).

Survival International (d.n.i.): Los indígenas aislados del Perú. Date not indicated. Available at: https://www.survival.es/indigenas/aisladosperu (accessed 17 September 2019).

Three decades of deforestation from artisanal gold mining in the Peruvian Amazon, CINCIA, Research Brief No. 1., 2018, Available at: http://cincia.wfu.edu/wpcontent/uploads/CINCIA-Research-Brief-No.-1.pdf (accessed 30 July 2019).

Upper Amazon Conservancy: Intact but Threatened. Available at: https://upperamazon.org/threats/ (accessed 14 July 2019).

Villalobos Ruiz, José (2016): La creación de la comunidad nativa y sus efectos en la vida política de los pueblos awajún y wampis, Argumentos. Revista de análisis y crítica, No. 4. Año 10 Available at: https://revistaargumentos.iep.org.pe/articulos/creacion-comunidad-nativa/ (accessed 17 September 2019).

Villasante Cervello, Mariella (2014): La violencia senderista entre los ashaninka de la selva central. Datos intermediarios de una investigación de antropología política sobre la guerra interna en el Perú (1980-2000). Documento de trabajo, IDEHPUCP. 
World Gold Council (2018): Gold mine production. Available at: https://www.gold.org/goldhub/data/historical-mine-production (Accessed 27 July 2019).

WWF (2011): De Purús para la Amazonía: el retorno de la caoba. Available at: http://www.wwf.org.pe/?199871/DePursparalaAmazona (accessed 3 July 2019).

WWF (2017): The Rainforest's Comeback: an innovating initiative recovers soils degraded by mining in Madre de Dios, Peru. Available at: http://www.wwf.org.pe/informate/noticias_new/noticias/?uNewsID=319354 (accessed 15 July 2019). 